\title{
Comparative Antibacterial Activities of Ficus abutilifolia Miq. (Moraceae) and Asimina triloba Dun. (Annonaceae) Leaf Ethanol Extract on Selected Bacteria
}

\author{
C. A. Ukwubile \\ Medicinal Plants Research Laboratory, Central Academic Center / Sancta Maria Clinic Integrated Laboratory \\ Bali, Nigeria. \\ *Corresponding Author: C. A. Ukwubile, Medicinal Plants Research Laboratory, Central Academic \\ Center / Sancta Maria Clinic Integrated Laboratory Bali, Nigeria.
}

\begin{abstract}
Medicinal plants have been used since time immemorial for the treatment of various ailments ranging from fevers to all kinds of infections in health care delivery systems especially in developing worlds. This present study was aimed at evaluating antibacterial properties of Ficus abutilifolia and Asimina triloba on selected bacterial strains. The selected bacterial strainare Salmonella typhi ATCC23564, Staphylococcus aureus ATCC29213, Streptococcus pyogenes ATCC8668, Campylobacter jejuni, VRE ATCC2025 and Shigella dysenteriae. The result VRE ATCC2025 with 49 \pm 0.70 showed that S. typhi had highest diameter zone of inhibition $(58 \pm 1.02 \mathrm{~mm})$ followed by the least $S$. dysenteriae $(25 \pm 0.38 \mathrm{~mm})$ of $F$. abutilifolia extract but the bacteria were resistant to A. triloba ethanol extract. These results were compared to the diameter zone of inhibition of the standard drug which was significantly different. The study revealed that F. abutilifolia ethanol leaf extract possessed antibacterial properties against the bacterial strains as well as greater minimum inhibition concentration (MIC) and minimum bactericidal concentration (MBC). The study therefore showed that ethanol leaf extract of Ficus abutilifolia possessed anti-typhoid and antibacterial properties and justifies its use as an ethnomedicinal prescription in traditional medicine.
\end{abstract}

Keywords: Antibacterial, Ficus abutilifolia, Asimina triloba, zone of inhibition, MIC, MBC.

\section{INTRODUCTION}

Bacteria (singular: bacterium) constitute a large Domain of prokaryotic. Most bacteria have rigid cell walls, of which there are several types. These walls are important for preventing bacterial cell from bursting. The cell wall can also indicate the cell shape, usually one of three basic shapes; round, rod and spiral. The famous research bacterium and common cause of food poisoning is rod-shape, acme disease caused by the bite of an infected tick (Angela, 2012).

In biological communities surrounding hydrothermal vent and cold seeps, bacteria provide the nutrient needed to sustain life by converting dissolved compounds such as hydrogen sulphide and methane to energy (Choi and Charles, 2013; Gland et al., 2013). Bacterial are often maligned as the cause of human and animal disease. They are of such immense importance because of their extreme flexibility, capacity for rapid growth and reproduction and the oldest fossils known; nearly 3.5 billion years old are fossils of bacteria-like organisms (Stephen et al., 2012).

Many plants produce special substance in their roots, leaves, flower or seeds that help them to survive, Herbal medicines has its origin in ancient cultures including those Egyptians, American, Indian and Chinese, it involves the medical use of plant to treat disease and enhance general health and wellbeing, some herbs have potent ingredient and should be treated with same care and respect as pharmaceutical drug.

Ficus abutilifolia is a small tree, bark smooth and creamy-white, the trunk twisted and branching low; leaves alternate, hairless, leathery, almost circular, vein yellow-green conspicuous. It is called "Wan" in Hausa language, "Lapalapa" in Yoruba language and "Agbu inu" in Igbo language. The flowers are borne singly branches, green with cream spot, turning red when ripening (Hyde et al., 2016). The large-leaved rock fig is generally encountered on rocky hillside, rocky outcrop and along 
Comparative Antibacterial Activities of Ficus abutilifolia Miq. (Moraceae) and Asimina triloba Dun. (Annonaceae) Leaf Ethanol Extract on Selected Bacteria

streams. The species is always found on or near rock outcrop (Burrows and Burrows, 2003). It is restricted to the African continent.

Asimia triloba on the other hand, has a succulent fruits and it is a large plant of the Family Annonaceae that is considered a tree. The fruit is spherical to cylindrical 75 to $500 \mathrm{~mm}$. It contain black seeds inside about $0.6 \mathrm{~cm}$ in diameter; each enclosed in gelatinous membrane shade. It has a more open branching habit with few lower limbs and horizontal held leaves (Orwa et al.,2009). Native to Central America, pawpaw has been grown throughout the tropics, where it is extensively cultivated, and as far North and South as 320 latitude; almost many in some areas of tropics.

This present study was carried out to evaluate comparatively the antibacterial activities of $F$. abutilifolia and A. triloba to justify their ethnomedicinal use in traditional medicine.

\section{Materials AND MethodS}

\section{Plants collection and identification}

The Asimina triloba and Ficus abutilifolia leaves were collected on the April 2016 from Bali Local Government Area, Taraba State, and was identified by Mr. Cletus A. Ukwubile of the Department of Science Laboratory Technology, Federal Polytechnic Bali, Taraba State where voucher numbers were deposited for the plants.

\section{Determination of antibacterial activities of leaf extracts}

The leaf extracts were screened for antibacterial activity using the agar well diffusion method as described by Akinpelu (1999). With the aid of a sterile $1 \mathrm{~mL}$ pipette; $0.2 \mathrm{~mL}$ of the broth culture of the test organism was added to $18 \mathrm{~mL}$ of blood agar which had already cooled down to $45^{\circ} \mathrm{C}$. This was well mixed and poured into already labelled sterile Petri dish according to the test organisms. The medium was then allowed to set with the aid of sterile cork borer. The required numbers of holes were bored into the medium. The wells were then filled up aseptically with the solution of the leaf extracts using sterile pasture pipette. Ciprofloxacin USP, was used as the standard antibacterial agent at a concentration of $1 \mathrm{mg} / \mathrm{mL}$. The plates were allowed to stand for about $1 \mathrm{~h}$ on the bench to allow proper diffusion of the antibacterial agent into the medium and then incubated upright at 300C for $24 \mathrm{~h}$. Adequate care was taken not to stockpile the plates. Clear zones of inhibition indicate the relativesusceptibility of the bacteria to the extract. This was measured in millimetres $(\mathrm{mm})$ using transparent ruler.

\section{Determination of minimum inhibitory concentration of extracts (MIC)}

The minimum inhibitory concentration of the leaf extracts was determined using the method of Russel and Furr (1977). Different concentration of leaf extracts were used which include $20 \mathrm{mg} / \mathrm{mL}, 10$ $\mathrm{mg} / \mathrm{mL}, 5 \mathrm{mg} / \mathrm{mL}, 2.5 \mathrm{mg} / \mathrm{mL}$, and $1.25 \mathrm{mg} / \mathrm{mL}$. Exactly $2 \mathrm{~mL}$ of the extract from each dilution was pipetted into sterile plate with the aid of a sterile pipette and then mixed with $18 \mathrm{~mL}$ blood agar plate and allowed to dry before streaking with overnight broth cultures of the microbes. The plate were then labelled accordingly and incubated at $37^{\circ} \mathrm{C}$ for 48 hours. They were later examined for the presence or absence of bacterial growth. The lowest concentration preventing growth was taken as the minimum inhibitory concentration (MIC) of the extract.

\section{Determination of minimum bactericidal concentration (MBC) of the extract}

The MBC was carried out in order to determine whether the microbes were killed or only their growths were inhibited. Blood agar was prepared according to the manufacturer's instructions and sterilized at $121^{\circ} \mathrm{C}$ for 15 minutes. It was poured into sterile Petri dishes and left to solidify. The plates were labelled accordingly to correspond to the MIC test tubes. The contents of the MIC in the proceeding test tubes in the serial dilution were sub cultured into the plates by dipping a sterile wire loop and streaking the surface of the agar, in the plates. The plates were thus incubated at $37^{\circ} \mathrm{C}$ for 24 hours after which they were checked for growth. The plate with the lowest concentration of extract without growth was taken as the MBC.

\section{Statistical analysis}

All statistical analysis was based on the student's t-test by Snedecor and Cochran (1967).

\section{RESULTS AND DISCUSSION}


Comparative Antibacterial Activities of Ficus abutilifolia Miq. (Moraceae) and Asimina triloba Dun. (Annonaceae) Leaf Ethanol Extract on Selected Bacteria

Medicinal plants have been used by several human communities to treat diverse disease, including infection. They therefore constitute a potential source for the production of new medicine which may enhance the effect of the conventional antimicrobials. Moreover, the search for effective antibacterial agent from natural sources such as plant has become necessary in order to overcome the problem of bacterial resistance.

Table 1. Zones of inhibition of leaf extracts against the microbes

\begin{tabular}{|l|c|c|c|}
\hline \multirow{2}{*}{ Test Organism } & \multicolumn{3}{|c|}{ Mean zone of inhibition \pm SEM } \\
\cline { 2 - 4 } & FA & AT & Ciprofloxacin \\
\hline Staphylococcus aureus & $27 \pm 0.14$ & 0 & 0 \\
Streptococcus pyogenes & 0 & 0 & $37 \pm 0.60$ \\
Salmonella typhi & $58 \pm 0.60^{*}$ & 0 & $41 \pm 0.11^{*}$ \\
Shigella dysenteriae & $25 \pm 0.38$ & 0 & $32 \pm 0.05$ \\
VRE ATCC2025 & $49 \pm 0.70$ & 0 & 0 \\
C. jejuni & $41 \pm 0.64$ & 0 & 0 \\
\hline
\end{tabular}

Zero (0) denotes organism that showed resistant to the drugs, FA; Ficus abutilifolia leaf extract, AT ; Asimina triloba leaf extract, SEM; Standard error of mean, $* \mathrm{p}<0.05$ statistical significance (t- test), $\mathrm{n}$ $=3$.

From the table above, Salmonella typhi ATCC23564 showed the highest zone of inhibition against the bacteria with $58 \pm 0.60$ and followed by Vancomycin resistance enterococcus (VRE ATCC2025) with $49 \pm 0.70$ mean diameter zone of inhibition.

*Most of the bacterial strains were standard strains from American type culture collection (ATCC). They include: Staphylococcus aureus ATCC29213, Streptococcus pyogenes ATCC8668, Salmonella typhi ATCC23564, VRE ATCC2025, while the remaining two are clinical isolates.

Table 2. Minimum inhibitory concentration (MIC) and minimum bactericidal concentration (MBC) of leaf extract against the microbes

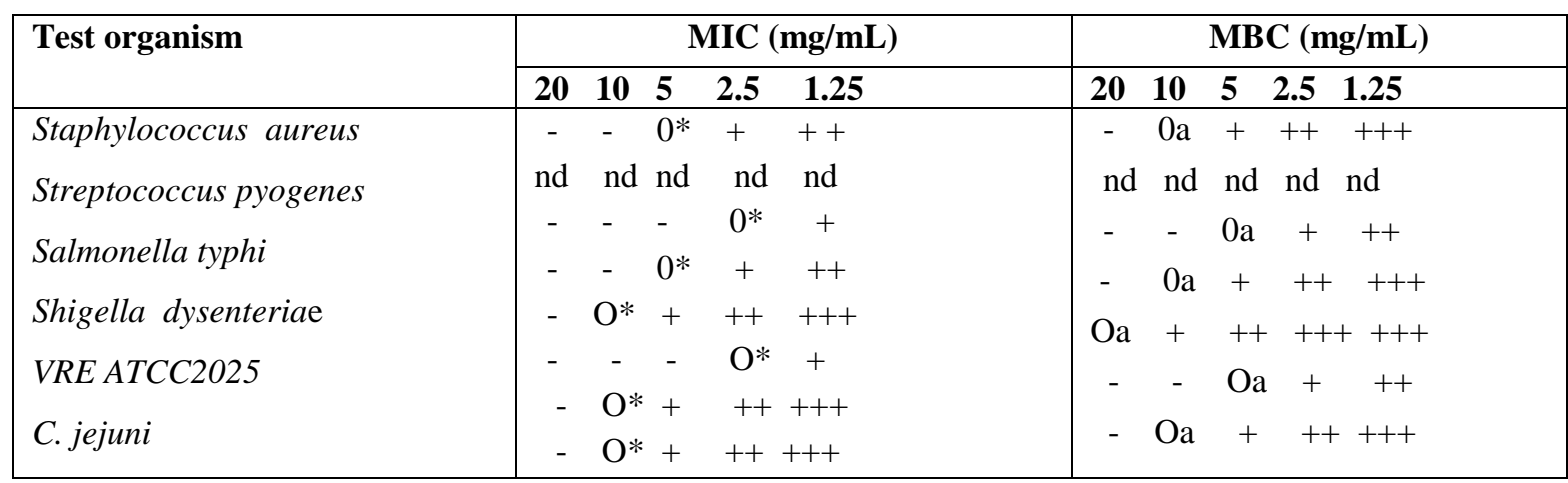

Note: - (clear), + (light growth), ++ (dense growth), $0^{*}$ (MIC), Oa (MBC), +++ (high growth), nd (not determined).

From the table 2 above, most of the bacteria were able to inhibit the growth of the bacteria at concentration less than $20 \mathrm{mg} / \mathrm{mL}$ from the determined strains of microbes.

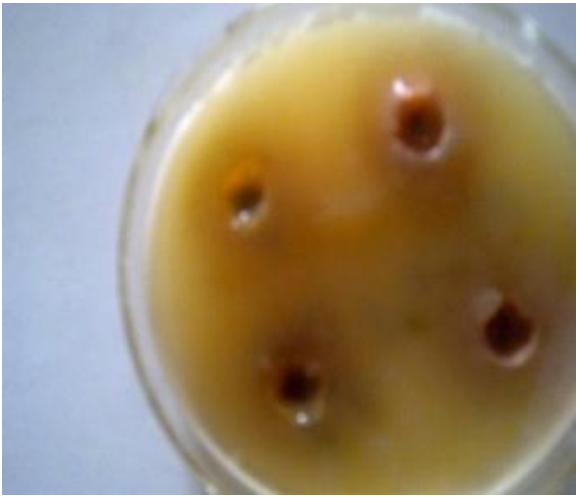

S. pyogenes ATCC8739 (a )

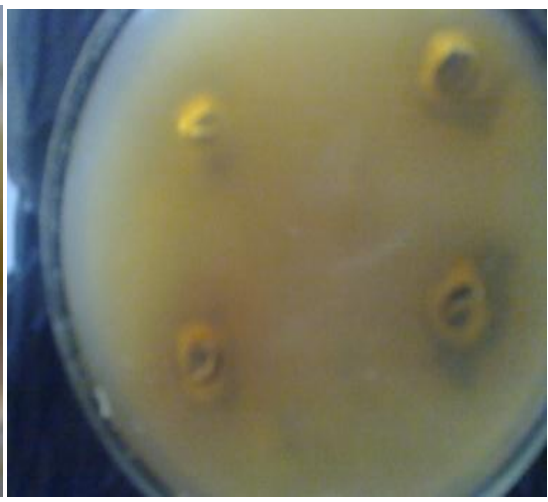

S. typhi ATCC23564 (b) 
Plate 1. Disc for zones of inhibition of extract of F. abutilifolia

From the present study, Salmonella typhi showed the highest diameter zone of inhibition of $58 \mathrm{~mm} \pm 0.60 \mathrm{~mm}$ which is significantly different from the standard drug ciprofloxacin tablet (USP) with inhibition zone of $41 \mathrm{~mm} \pm 0.11 \mathrm{~mm}$ (table 1). This result was in support of the work by Ukwubile and Nuhu (2010) when they reported that ethanol leaf extract of Ficus abutilifolia possess antibacterial efficacy against Salmonella typhi. This may account for the over whelming use of the leaf in the treatment of typhoid fever caused by Salmonella typhi. Also at concentration $2.5 \mathrm{mg} / \mathrm{ml}$, this bacterium has a MIC against the extract. At this point, the growth of the organisms was inhibited as can be seen in the results (table 2).The MBC was shown by the extract against Salmonella typhi at concentration $5.0 \mathrm{mg} / \mathrm{mL}$ of the extract which suggest that the organism was killed or its growth totally inhibited at this concentration.

Salmonella typhi is a facultative anaerobic Gram-negative rod belonging to Enterobacteriaceae family. It is strictly a human pathogen. Typhoid fever affects approximately 17 million people globally each year and causes 600,000 deaths. In Europe and America, typhoid outbreak has been virtually eliminated. Cases reported in these areas have been imported by travellers from endemic areas of Africa, Asia, Middle East and Latin America (USFDA, 2009). Treatment of the disease with known antibiotics like ciprofloxacin tablet, ceftriaxone, ampicillin and chloramphenicol has shown multidrug resistance in these areas, and may account for the regular use of the leaf extract for the prompt treatment of the disease especially in Nigeria, where the infestation of the disease is through food and water consumed in an un-hygienic state .

Antibacterial agents affect the synthesis of peptidoglycan around a bacterial cell and the cell will die by osmotic shock (Banso and Adeyemo, 2006; Taiwo et al., 2016). Antibacterial agents with low activity against an organism have a high MIC while a highly active antibacterial agents gives a low MIC, and from this study, Salmonella typhi showed higher activities than the other bacteria (Staph. aureus and Shigella dysenteriae) tested. However, the fact that these two organisms were sensitive to the crude leaf ethanol extracts, suggest that the leaf extract can be used to treat diseases caused by these organisms. For instance, amoebic dysentery caused by Shigella dysenteriae and sexually transmitted infections caused by Staph. aureus.

F. abutilifolia leaf extract exhibit the highest degree of antibacterial activities against $S$. typhi than Asimina triloba leaf extract and this effect was also compared favourably with that of standard antibiotic ciprofloxacin used as the control. The broad spectrum and high activities exhibited by $F$. abutilifolia extract against $S$. typhi showed that the plant could be a good source for the treatment of infectious disease in human.

\section{CONCLUSiON}

The potency exhibited by $F$. abutilifolia leaf extract against $S$. typhi and other bacteria used in this study at low concentration and minimal contact time has shown that drugs formulated from this plant will go a long way in health care delivery. The present study support the acclaimed uses of $F$. abutilifolia in the traditional system to treat various infectious disease caused by pathogenic microbes. It is therefore recommended that further studies be carried out with a view to knowing the compound responsible for the observed biological activity. Antimicrobial activity of various solvent fractions is hereby recommended also for comparing results.

\section{ACKNOWLEDGEMENT}

The author is grateful to Mr. Mika Nurah of Microbiology Department, National Leather Research, Zaria who supplied the bacterial strains, and to Magret Omotosho who collected the plants and dried them.

\section{REFERENCES}

Akinpelu, D. A. (1999). Antimicrobial activity of Vernonia amygdaline leaves. Fitoterapia, (3): 290 - 292

Angela,P.K.(2012). What is bacteria? http:study.com/academy/lesson/what-is-Eubacteria definition-characteris tic examples.htmlstudy.com

Banso, M. A. Adeyemo, J.J. (2006). A common mechanism of cellular death induced by bacterial antibiotics. Cell Communication Journal, 130:797-810. 
Comparative Antibacterial Activities of Ficus abutilifolia Miq. (Moraceae) and Asimina triloba Dun. (Annonaceae) Leaf Ethanol Extract on Selected Bacteria

Burrows, .J. \& Burrows, S. (2003). Figs of Southern and South - Central African Umdaus Press, Hatfield

Choi, K., Charles, Q., and Peterson, J.K. (2013). Microbes thrives in deepest spot on earth. Live Science Retrieved, 17 (3): 23-27.

Gland, W., Shian-Ren L., Plunkett, G., Mayhew, M.D., Rose, D.J, Blattner, F.R. (2013). comparative genomics of Salmonella enterica serovar typhi strain Ty2 and $\mathrm{CT}_{18}$. Journal of bacteriology, 185:2330-2337.

Hyde, M. A., Wursten, B.T., Coates, H.L. and Palgrave, M. (2016). Flora of Zimbabwe species information Ficus abutilifolia./www.ztmbabweflora.co.zw/species data/species.php.species=120210 Retrieved, 26: 23.

Orwa, C.A., Mutua,A., Kindt, R., Jamnadass, R. S. (2009 ). Agroforest tree base: a tree reference and guilde version4.

Russell, A. D. and Furr, F. R, (1977). The antibacterial activity of a new chloroxylenol preparation containing ethylenediaminete-traacetic acid. Journal of applied Bact., 43: 253-260.

Snedecor, G.W. and Cochran, W.G. (1967). A statistical Method. Lowe State University Press, Ames, Lowe, $\mathrm{USA}(\mathrm{s})$

Stephen, N., Waggoner,G.I., Markus,P.L. (2012). Bacterial and the sickworld. Nature published in final edited for as: Nature 2012 January 189; 481 (7381): 394 - 398. Published online 2011 November 20 doi: 10. 1038/nature 10624.

Taiwo, F. O et al. (2016). Phytochemical constituents and antibacterial activity of Ficus abutilifolia. British Journal of Pharmacy Research, 12(3): 123-127. www.sciencedomaine. DIO10.9734/BJPR/2016/25608.

Ukwubile, C.A. and Nuhu, H.I.(2010). Pharmacognostic, antibacterial and toxicity investigation of Ficus abutilifolia Miq. (Moraceae). International Journal of Biological Sciences, 8(4): 100-115.

USFDA (2009). Antibiotics susceptibility study by disc diffusion.

Citation: C. A. Ukwubile, "Comparative Antibacterial Activities of Ficus abutilifolia Miq. (Moraceae) and Asimina triloba Dun. (Annonaceae) Leaf Ethanol Extract on Selected Bacteria ", International Journal of Research studies in Microbiology and Biotechnology, vol. 4, no. 2, p. 6-10, 2018. http://dx.doi.org/10.20431/ 2454-9428.0402002

Copyright: (C) 2018 Authors. This is an open-access article distributed under the terms of the Creative Commons Attribution License, which permits unrestricted use, distribution, and reproduction in any medium, provided the original author and source are credited. 